\title{
RAHASIA DAGANG MASAKAN CHAKE \\ CIRI KHAS KULINER KABUPATEN SUMENEP \\ (STUDI KASUS SAMPOERNA CATERING DI SUMENEP)
}

\author{
Anita ${ }^{(1)}$ \\ Meidy Triasavira ${ }^{(2)}$ \\ Dosen Fakultas Hukum Universitas Wiraraja ${ }^{(1)}$ \\ Mahasiswa Fakultas Hukum Universitas Wiraraja ${ }^{(2)}$ \\ anita.wiraraja19@gmail.com ${ }^{(1)}$ \\ meidy.triasavira8419@gmail.com ${ }^{(2)}$
}

\begin{abstract}
ABSTRAK
Penulisan ini bertujuan untuk mengetahui kondisi cukup atau tidaknya suatu perlindungan hukum rahasia dagang atas suatu informasi bisnis pada suatu catering yaitu "Sampoerna Catering" di Kabupaten Sumenep. Hasil penelitian ini menunjukkan bahwa perlindungan hukum atas rahasia dagang pada catering tersebut sudah cukup, walaupun disisi lain masih ada kelemahan dan kekurangan. Kekurangan itu mencakup aturan-aturan formal dalam catering tersebut belum secara penuh melindungi resep rahasia dagang, kurangnya pengetahuan lebih yang dimiliki oleh pihak pemilik dan karyawannya mengenai UndangUndang Rahasia Dagang yan telah mengatur segala sesuatu yang bersifat rahasia dan memiliki nilai ekonomi. Penelitian ini merekomendasikan perlunya sosialisasi lebih mengenai Undang-Undang Rahasia Dagang karena minimnya pengetahuan yang dimiliki oleh pihak pemilik dan lebih memperketat tata tertib dan segala ketentuan yang dapat mengakibatkan bocornya rahasia dagang tersebut.
\end{abstract}

Kata Kunci : Perlindungan Hukum, Rahasia Dagang, Ciri Khas, dan Kuliner. 


\section{IURNAL JENDELA HUKUM}

\section{A. PENDAHULUAN}

Perkembangan pada zaman sekarang mendorong munculnya perubahan di berbagai bidang, terutama di bidang ekonomi, khususnya dalam bidang bisnis. Bisnis merupakan kegiatan dalam memenuhi kebutuhan masyarakat dengan menciptakan barang atau jasa untuk mendapatkan keuntungan dalam memingkatkan kualitas hidup mereka. Selain itu, berkembangnya ilmu pengetahuan, teknologi dan informasi yang maju dengan pesat, mengakibatkan peningkatan persaingan dalam dunia bisnis. Mengingat dunia bisnis dewasa ini, banyak dilakukan lewat waralaba, pemilik Hak Atas Kekayaan Intelektual (HAKI) dalam hal ini pemegang rahasia dagang berharap rahasia dagangnya mendapatkan perlindungan hukum. Untuk itu pemerintah Republik Indonesia pada tanggal 20 Desember 2000 menerbitkan Undang-Undang Nomor 30 Tahun 2000 tentang Rahasia Dagang, lembaran Negara Republik Indonesia Nomor 242 Tahun 2000. ${ }^{1}$

Menurut Pasal 1 Undang-Undang Nomor 30 Tahun 2000 Tentang Rahasia Dagang adalah informasi yang tidak diketahui oleh umum di bidang teknologi dan/atau bisnis, mempunyai nilai

1 Aulia Muthiah, Aspek Hukum Dagang Dan Pelaksanaannya Di Indonesia, Cetakan Pertama, Yogyakarta: Pustaka Baru Press, 2016, h. 165 .
ISSN Cetak \& Online : 2355-5831/ 2355-9934

ekonomis karena berguna dalam kegiatan usaha dan dijaga kerahasiaannya oleh pemilik Rahasia Dagang. Hal yang dimaksud dengan hak atas rahasia adalah hak atas rahasia dagang yang timbul berdasrkan Undang-Undang Rahasia Dagang. $^{2}$

Pelaku bisnis harus memiliki temuan baru atau inovasi baru dalam lingkup bisnis dimana bertujuan untuk meningkatkan perekonomian. Aktivitas tersebut dilakukan untuk menciptakan suatu hal yang kreatif, dimana proses mewujudkan ide atau gagasan untuk menjadi kekayaan intelektual. Aktivitas intelektual mencakup sarana prasarana, biaya, waktu, dan tenaga. Jika semua itu terpenuhi, maka aktivitas tersebut akan menghasilkan kekayaan intelektual, oleh karena itu perlu dijaga kerahasiaan informasi temuan tersebut yang disebut juga rahasia dagang.

Tidak semua penemu atau kalangan pengusaha berusaha mengungkapkan temuannya. Mereka tetap ingin menjaga kerahasiaan karya intelektual mereka. Walaupun bagaimana kerahasiaan karyakarya intelektual merupakan kepentingan yang perlu dilindungi, dikarenakan dimana persaingan usaha tidak terpisahkan dari kehidupan para pengusaha untuk memperoleh laba yang

2 Yusran Isnaini, Buku Pintar HAKI, Bogor: Ghalia Indonesia, 2010, h.97 


\section{JURNAL JENDELA HUKUM}

ISSN Cetak \& Online : 2355-5831/ 2355-9934

sebesar-besarnya atau untuk mencapai keuntungan. ${ }^{3}$

Jika suatu informasi teknik maupun bisnis yang dimiliki oleh sesorang atau badan hukum walaupun bernilai ekonomis, tetapi pemiliknya tidak berupaya menjaga kerahasiannya, tidak dapat dikategorikan sebagai rahasia dagang. Harus ada "upaya-upaya sebagaimana mestinya" menjaga kerahasiaannya.

Semakin berkembangnya usaha kuliner di Indonesia terutama pada bidang catering pada masa ini dimana membuat persaingan usaha di Indonesia menjadi sangatlah menjanjikan untuk mendapatkan laba dan keuntungan.

Langkah-langkah untuk menjaga kerahasiaan dagang perlu dilakukan oleh setiap pelaku usaha agar kerahasiaan dagang tersebut tidak dibocorkan oleh pihak lain yang berwenang. Langkah tersebut dapat dilakukan dengan berbagai cara sesuai dengan ketentuan dan kebijakan yang telah ditetapkan oleh pemilik catering tersebut.

Pelanggaran informasi Rahasia Dagang terjadi pada salah satu catering di Kabupaten Sumenep yang berkenaan dengan kerahasiaan, dimana salah satu catering tersebut mampu bertahan

3 Sudikno mertokusumo, Mengenal Hukum Suatu Pengantar, Yogyakarta: Liberty, 2008, h. 64. hingga 10 (sepuluh) tahun, dan menjadikan catering sebagai salah satu usaha yang menjajikan. Hal ini menjadi salah satu faktor ketertarikan pelaku usaha lainnya, untuk mendirika sebuah catering baru. Bahkan tidak sedikit pelaku usaha atau pemilik catering tersebut adalah orang yang pernah bekerja di suatu catering sebelumnya.

Kasus pelanggaran rahasia dagang ini dilakukan oleh mantan karyawan dari sebuah catering yang mengakibatkan catering tersebut mengalami kegoyahan, dimana ia telah bekerja kurang lebih selama 8 (delapan) tahun dan telah mengetahui apa saja yang menjadi rahasia dalam catering terdahulu. Setelah menguasai resep dan tidak bekerja lagi di catering tersebut, mantan karyawan tersebut mebuka usaha dengan model yang sama.

Saat itu catering terdahulu memiliki sebuah resep andalan yaitu masakan ciri khas kuliner Kabupaten Sumenep yang bernama "Chake" yang mana pada catering ini terkenal cita rasa yang berbeda. Namun resep andalan ini diketahui oleh mantan karyawan tersebut dan dia membuat menu yang sama di tempat usaha catering barunya. Bermodal pengalaman yang telah dipelajari selama bekerja di catering terdahulu.

Inovasi baru dari masakan "Chake" 


\section{JURNAL JENDELA HUKUM}

ISSN Cetak \& Online : 2355-5831/ 2355-9934

tersebut melahirkan cita rasa yang baru, yang dapat digunakan untuk meningkatkan nilai perekonomian dan meningkatka usahanya. Resep masakan "Chake" tersebut haruslah dilindungi, apabila tidak diberikan perlindungan, maka berdampak lahirnya persaingan usaha secara tidak sehat dalam masyarakat. Seiring berjalannya waktu, akhirnya catering terdahulu mengalami penurunan omset. Hal ini tentunya dilakukam tanpa sepengetahuan pemilik catering terdahulu sehingga secara tidak langsung mengakibtkan kerugian pada pemegang hak Rahasia Dagang. Pada kenyataannya permasalahan mengenai rahasia dagang ini tidak sampai pada pengadilan dikarenakan pemilik catering tersebut tidak mengetahui bahwa usahanya dilindungi oleh UndangUndang Rahasia Dagang, dengan demikian dapat disadari betapa pentingnya suatu perlindungan hukum terhadap hasil karya penemuan yang dikategorikan sebagai rahasia dagang.

Dari uraian latar belakang tersebut, dapat dirumuskan permasalahan "Bagaimanakah konsekuensi hukum terhadap pelanggaran dalam menjaga kerahasiaan dagang pada catering "Sampoerna Catering"?

\section{B. PEMBAHASAN}

Perlindungan hukum bagi Rahasia Dagang yang dikehendaki adalah perlindungan hukum yang kebih spesifik dan khusus terhadap informasi di bidang teknologi dan perdagangan yang sifatnya rahasia dan sangat bernilai secara ekonomi bagi pemiliknya dalam menjalankan usaha bisnisnya. ${ }^{4}$ Secara Pidana diberi perlindungan pada Rahasia Dagang yaitu dengan sanksi pidana seperti pada Pasal 323 KUHPidana dan juga secara perdata dalam pasal pokok tentang perbuatan melanggar hukum, yaitu Pasal 1365 BW.

Pemilik atau pemegang Rahasia Dagang selain peralihan melalui warisan, juga dapat menggunakan haknya untuk bebas melakukan pengalihan hak atau perikatanperikatan serta perjanjian dengan pihak lain melalui perbuatan hukum. Misalnya dengan cara menghibahkan, mewasiatkan atau dengan bentuk perjanjian lain selama tidak bertentangan dengan ketentuan hukum Rahasia Dagang atau ketentuan hukum lainnya. Selain daripada perbuatan hukum atas Rahasia Dagang dari pemiliknya, kepemilikan Rahasia Dagang juga dapat beralih karena peristiwa hukum yaitu dengan pewarisan karena Rahasia Dagang dianggap sebagai suatu barang hak milik. Berkaitan dengan terjadinya pelanggarang Rahasia Dagang,

${ }^{4}$ Adami Chazawi, Tindakan Pidana Hak Atas Kekayaan Intelektual (HAKI), Malang; Banyumedia Publishing, 2007, h. 207. 


\section{JURNAL JENDELA HUKUM}

ISSN Cetak \& Online : 2355-5831/ 2355-9934

apabila ada pihak lain selain pemilik atau pemegang Rahasia Dagang yang dengan sengaja mengungkapkan Rahasia Dagang sehingga menginkari kesepakatan atau mengingkari kewajiban tertulis atau tidak tertulis untuk menjaga Rahasia Dagang yang bersangkutan, maka pemegang/ Pemilik Rahasia Dagang dapat menggunakan Haknya untuk menggugat pihak lain tersebut ke pengadilan Negeri dengan gugat ganti rugi, biaya dan bunga sesuai dengan ketentuan dalam KUH Perdata. Hal ini sesuai dengan Pasal 11 jo Pasal 13 Undang-undang Nomor 30 tahun 2000 tentang Rahasia Dagang.

Dengan adanya UURD sekarang, perlindungan hukum terhadap pemegang hak Rahasia Dagang semakin kua. Secara perdata dengan ditegaskannya hak menggugat kepada pihak-pihak yang melanggar hak rahasia dagang, perlindungan hukum perdata semakin mendapat kepastian hukum. Dalam hal apa yang dapat dituntut dalam gugatan perdata, dan dengan alasan apa serta diajukan ke mana gugatan tersebut telah diatur sedemikian rupa. Tentu saja gugatan perdata karena pelanggaran hukum UURD bisa didasarkan pula pada Pasal 1365 BW sebagai ketentuan dasar umumnya. ${ }^{5}$

$\begin{array}{ccr}\text { Pelanggaran } & \text { Rahasia } & \text { Dagang } \\ \text { dianggap terjadi } & \text { apabila } & \text { seseorang }\end{array}$

${ }^{5}$ Adami Chazawi, Op. Cit., h. 209 dengan sengaja mengungkapkan Rahasia Dagang, mengingkari kesepakatan atau mengingkari kewajiban tertulis atau tidak tertulis untuk menjaga Rahasia Dagang yang bersangkutan. Jadi, seseorang dianggap melanggar Rahasia Dagang pihak lain apabila ia memperoleh atau menguasai Rahasia Dagang tersebut dengan cara bertentangan dengan peraturan perundang-undangan yang berlaku. Apa yang merupakan peraturan perundang-undangan yang berlaku bahwa ia tidak diperbolehkan untuk tanpa suatu dasar hukum memperoleh atau menguasai Rahasia Dagang. ${ }^{6}$

Apabila upaya-upaya menjaga kerahasiaan telah dilakukan sesuai UU Rahasia Dagang, maka jika terjadi penggunaan atau pengungkapan informasi rahasia tersebut kepada pihak ketiga untuk kepentingan komersial, dapat diduga telah terjadi pelanggaran rahasia dagang. Pemegang Hak Rahasia Dagang atau penerima Lisensi dapat mengambil tindakan hukum pula secara perdata sesuai dengan Pasal 11 UURD, terhadap siapa pun yang dengan sengaja dan tanpa hak melakukan pelanggaran rahasia dagang dengan cara mengungkapkan rahasia dagang, mengingkari kesepakatan atau

${ }^{6}$ Sudargo Gautama dan Rizwanto Winata, Komentar Atas Undang-Undang Rahasia Dagang Tahun 2000, Bandung: PT. Citra Aditya Bakti, 2003, h. 114-115 


\section{IURNAL JENDELA HUKUM}

mengingkari kewajiban tertulis atau tidak tertulis untuk menjaga rahasia dagang yang bersangkutan secara sengaja. Pelanggaran juga dianggap terjadi pada saat seseorang memperoleh atau menguasai rahasia dagang tersebut dengan cara yang bertentangan dengan peraturan perundang-undangan yang berlaku. $^{7}$

Dalam pasal 323 ayat 2 disyaratkan pula adanya pengaduan dari pengusaha untuk dapat mengajukan tuntutan (delik aduan). Melihat pada peraturan perundangan di bidang ketenagakerjaan, maka pelanggaran rahasia dagang yang dilakukan oleh buruh dapat mengacu pula pada Keputusan Menteri Tenaga Kerja RI (KepmenTK) No. 150/Men/2000 tanggal 20 Juni 2000. Dalam Kepmen. TK tersebut pada pasal 18 ayat 1 (j), dinyatakan bahwa buruh yang melakukan tindakan membongkar atau membocorkan rahasia perusahaan atau mencemarkan nama baik pengusaha dan atau keluarga pengusaha yang seharusnya dirahasiakan kecuali untuk kepentingan negara, dapat diberikan ijin kepada pengusaha untuk melakukan pemutusan hubungan kerja (PHK) terhadap buruh tersebut. Ijin PHK ini diberikan oleh P4 (Panitia Penyelesaian

\footnotetext{
${ }^{7}$ Moses Grafi, Tesis Perlindungan Hukum Rahasia Dagang Ditinjau Dari Aspek Perdata dan Aspek Pidana Menurut Undang-Undang Nomor 30 Tahun 2000 Tentang Rahasia Dagang.
}

Perselisihan Ketenagakerjaan) Daerah untuk PHK perorangan atau P4 Pusat untuk PHK massal. Terjadinya pengungkapan informasi yang dimiliki satu pihak kepada pihak lainnya tanpa diketahui oleh pihak pemilik informasi dapat menimbulkan kerugian bagi pemilik informasi tersebut. Pengungkapan informasi dapat dilakukan dilakukan oleh tenaga kerja dari pemilik informasi. Cara perusahaan dalam mengelola dan mengontrol informasi rahasia perusahaan sangat mempengaruhi bagaimana pekerjanya akan menjaga kerahasiaan informasi tersebut.

Resep yang menjadi masakan andalan pada catering tersebut telah bocor, dimana suatu rahasia dagang dapat dikatakan rahasia dan mendapat perlindungan hukum apabila merupakan informasi yang dirahasiakan, memiliki nilai komersial dan ada upaya pemiliknya untuk mejaga rahasia dagang tersebut. Namun dikarenakan rahasia dagang tersebut hilang atau hapus. Berarti mengakibatkan hak eksklusof dari resep terseut sudah tidak ada dan resep tersebut dapat digunakan oleh pihak lain, karena unsur kerahasiaannya sudah hilang.

\section{KESIMPULAN}

Pembocoran rahasia dagang dikategorikan sebagai perbuatan melawan hukum dalam bidang HKI yang 


\section{JURNAL JENDELA HUKUM}

ISSN Cetak \& Online : 2355-5831/ 2355-9934

telah diatur dalam Undang-Undang Nomor 30 Tahun 2000 tentang Rahasia Dagang. Karyawan berkewajiban terhadap majikannya melakukan segala sesuatu yang patut dan benar dimana setiap buruh berkewajiban mentaati aturan-aturan tentang segala hal yang termuat dalam tata tertib dalam suatu kegiatan usaha si majikan.

Pihak karyawan tidak diperbolehkan melakukan pembocoran Rahasia Dagang kepada pihak ketiga, maka pihak karyawan harus bertindak sebagai seorang buruh yang baik. Sifat kerahasiaan suatu informasi akan hilang dan menjadi milik umum apabila Rahasia Dagang tersebut bocor, maka berarti Rahasia Dagang tersebut sudah tidak dapat memiliki nilai ekonomi lagi bagi si pemilik Rahasia Dagang, dikarenakan pemilik Rahasia Dagang akan mengalami kerugian bahkan turunnya omset pemasukan yang didapatinya yang akan mengakibatkan usaha dari si pemilik Rahasia Dagang tersebut akan mengalami kebangkrutan. Sifat rahasia dagang dari menu tahu cocol tersebut menjadi hilang dikarenakan telah bocornya resep tersebut dan telah diketahui oleh umum, jadi dapat disimpulkan bahwa resep tersebut sudah tidak bisa di anggap sebagai rahasia dagang karena diketahui oleh umum dan hak eksklusif dari resep tersebut sudah tidak ada atau hilang yang mengakibatkan orang lain dapat menggunakan resep tersebut dan bukan menjadi milik si pemilik resep tersebut.

Melakukan pembatasan akses terhadap para pegawai yang mengatahui atau memegang rahasia dagang tersebut, dimana setiap ruangan tertentu diberi batasan-batan area dilarang dimasuki dan hanya boleh dimasuki oleh orang-orang tertentu saja.

Pelaku usaha bisnis dimana harus lebih mengetahui aturan-aturan yang berlaku di negara ini, dan aparat penegak hukum lebih berperan aktif untuk meingkatkan pengetahuan bagi pelaku usaha tentang UURD, agar para pelaku usaha mengerti dan mengetahui bahwa segala sesuatu diatur oleh undangundang dan agar terciptanya kepastian hukum bagi sipemilik Rahasia Dagang dan mengerti akibat dan sanksi apa yang dapat diterapkan apabila ada yang melanggar ketentuan tersebut.

Tata tertib harus dibuat lebih spesifik dan lebih tegas oleh pelaku usaha, agar para karyawan lebih mengerti apa yang harus ia lakukan dan apa yang tidak boleh ia lakukan dan memberikan batasan-batasan akses bagi para pekerja. 


\section{JURNAL JENDELA HUKUM}

ISSN Cetak \& Online : 2355-5831/ 2355-9934

\section{DAFTAR BACAAN}

\section{Buku}

Aulia Muthiah, Aspek Hukum Dagang

Dan Pelaksanaannya Di

Indonesia, Cetakan Pertama, (Yogyakarta: Pustaka Baru Press, 2016)

Yusran Isnaini, Buku Pintak HAKI, (Bogor: Ghalia Indonesia, 2010)

Sudikno mertokusumo, Mengenal Hukum Suatu Pengantar, (Yogyakarta: Liberty, 2008)

Adami Chazawi, Tindakan Pidana Hak Atas Kekayaan Intelektual (HAKI), (Malang; Banyumedia Publishing, 2007)

Sudargo Gautama dan Rizwanto Winata, Komentar Atas Undang-Undang Rahasia Dagang Tahun 2000, (Bandung: PT. Citra Aditya Bakti, 2003)

Moses Grafi, Tesis "Perlindungan Hukum Rahasia Dagang Ditinjau Dari Aspek Perdata dan Aspek Pidana Menurut Undang-Undang Nomor 30 Tahun 2000 Tentang Rahasia Dagang,"

\section{Undang-Undang}

Undang-Undang Nomor 30 Tahun 2000 Tentang Rahasia Dagang. 